\title{
PENINGKATAN HASIL BELAJAR SENI BUDAYA DAN KESENIAN (SBK) MELALUI METODE ASISTENSI
}

\author{
Hasto Mulyoko \\ SMP Negeri 2 Nguter \\ Email: hastomulyoko1965@gmail.com
}

\begin{abstract}
Abstrak
Penelitian ini bertujuan untuk meningkatkan hasil belajar SBK materi Memainkan Asambel Musik Tradisional Nusantara melalui metode asistensi pada siswa kelas VIII C SMP Negeri 2 Nguter tahun pelajaran 2016/ 2017. Penlitian ini adalah Penelitian Tindakan Kelas (PTK) pada kelas VIII C sebanyak 32 siswa. Pengumpulan data menggunakan metode tes, observasi, wawancara, dan observasi. Alat pengumpulan data yang digunakan adalah soal tes, lembar observasi, dan pedoman wawancara. Indikator keberhasilan pelaksanaan PTK ini adalah meningkatnya hasil belajar SBK siswa yang ditunjukkan dengan meningkatnya persentase ketuntasan siswa minimal $85 \%$ dan meningkatnya nilai rata-rata kelas, minimal menjadi 70,00. Berdasarkan hasil penelitian ini, dapat disimpulkan bahwa "Metode asistensi dapat meningkatkan hasil belajar SBK materi Memainkan Asambel Musik Tradisional Nusantara pada siswa kelas VIII C SMP Negeri 2 Nguter tahun pelajaran 2016/ 2017".
\end{abstract}

Kata Kunci: hasil belajar SBK, asistensi.

\begin{abstract}
This research aimed to improve study achievement of art lesson that the material is playing traditional assemble Indonesia music on students of class VIII C SMP Negeri 2 Nguter academic year 2016/2017. The research is classroom action research on class VIII C for 32 students. Data collection use test, observation, and interview test. Instruments for data collection are test sum, observation paper, and interview guide. Indicator for the successful of classroom action research is there is improvement study achievement of art lesson that is showed by improving the percentageof students' minimal $85 \%$ and improvement of average class score, minimal to be 70,00. Based on the research result, can be concluded that "assistance method can improve study achievement of art lesson that the material is playing traditional assemble Indonesia music on students of class VIII C SMP Negeri 2 Nguter academic year 2016/ 2017.
\end{abstract}

Keywords: study achievement, assistance

\section{PENDAHULUAN}

Bertolak dari latar belakang anak yang memiliki kesulitan yang beragam, maka proses belajar mengajar Seni Budaya dan Kesenian (SBK) terasa sulit karena masing-masing siswa memiliki problema tersendiri terhadap pelajaran ini. Hal tersebut tidak jauh berbeda dengan kondisi proses belajar mengajar SBK di SMP Negeri 2 Nguter, khususnya kelas VIII. Proses pembelajaran SBK kurang berjalan 
dengan lancar, karena penggunaan metode pembelajaran yang kurang bervariasi. Kenyataan ini mengakibatkan antusias siswa pada pembelajaran SBK rendah, yang mengakibatkan hasil nilai SBK belum mencapai ketuntasan minimal, yaitu 70 .

Guru menjadi salah satu subjek dalam proses pembelajaran yang merasakan dampak langsung terhadap kegiatan proses pembelajaran SBK. Berdasarkan pengalaman guru mengajar di kelas VIII C, masih menggunakan metode ceramah dalam mengajar. Kegiatan tersebut dibantu pula dengan buku paket. Data tersebut menunjukkan proses pembelajaran yang kurang variatif dan tentu saja terasa monoton. Guru melakukan wawancara kepada sejumlah siswa kelas VIII C setelah melaksanakan proses pembelajaran SBK pada materi Memainkan Asambel Musik Tradisional Nusantara menyatakan bahwa proses pembelajaran yang telah dilaksanakan kurang menarik dan tidak bervariasi, sehingga minat siswa pada pelajaran SBK rendah. Guru dapat mengambil kesimpulan sementara bahwa pembelajaran SBK pada materi Memainkan Asambel Musik Tradisional Nusantara belum berjalan lancar. Banyak siswa yang masih bingung tentang konsep materi ini sehingga menyebabkan rendahnya nilai siswa, yang mana dari hasil tes pra penelitian pembelajaran SBK terdapat kurang dari 50\% siswa yang mencapai ketuntasan minimal. Sementara dari segi non tes terlihat jelas dari kurangnya minat siswa terhadap pelajaran SBK, siswa nampak bosan mengikuti pelajaran karena pengajar tidak menggunakan metode yang variatif dan menyenangkan.

Melihat kondisi pembelajaran SBK yang kurang memuaskan, membuat guru berpikir untuk menciptakan suasana proses pembelajaran SBK yang menyenangkan di kelas. Keinginan tersebut untuk menjawab harapan akan terciptanya sebuah proses pembelajaran SBK yang menyenangkan, variatif, dan tidak monoton, sehingga minat siswa terhadap pelajaran SBK meningkat dan prestasi pelajaran pun meningkat.

Beberapa permasalahan tersebut membuat guru berpikir untuk mencari sebuah metode yang tepat dalam proses belajar mengajar SBK. Terdapat beberapa metode yang bisa diterapkan dalam proses pembelajaran SBK agar lebih variatif dan tidak monoton, antara lain dengan menggunakan meode yang mendekatkan siswa untuk bermain seperti metode jigsaw, fishbowl, note taking pairs dan lain- 
lain. Namun guru mencoba mencari sebuah metode yang lebih kooperatif dengan tidak meninggalkan kesan menarik dan santai pada pelajaran SBK. Maka guru berniat menggunakan metode asistensi yang akan diujicobakan pada siswa kelas VIII C. Metode asistensi adalah metode yang dirancang agar siswa aktif, yang mana salah seorang siswa akan diberi tanggung jawab untuk menjadi seorang asisten bagi teman-temannya dalam satu kelompok guna menjelaskan materi dan penerapan dari konsep pelajaran yang telah diajarkan oleh guru (Rooijakkers,1993:84). Metode ini dipilih karena dapat menjembatani antara guru dan siswa dalam sebuah pengajaran, juga mengefektifkan waktu mengingat banyaknya materi yang harus diajarkan. Dengan tidak meninggalkan kunci tanggungjawab, metode asistensi diharapkan lebih mendekatkan hubungan diantara siswa dalam proses pembelajaran SBK, karena dengan metode asistensi, seorang asisten dapat belajar tenggang rasa dan bekerja sama untuk memecahkan masalah yang sedang dihadapi. Untuk membuktikan benar tidaknya metode asistensi dapat mengatasi masalah ini, maka perlu dilakukan penelitian.

Proses belajar merupakan proses yang dilakukan dengan memberikan masukan (input) dan akan menghasilkan keluaran (output). Untuk mengetahui apakah siswa berhasil atau tidaknya dalam mengikuti kegiatan belajar adalah dengan melihat hasil belajar melalui sebuah tes yang dibuat oleh guru. Poerwadarminto (2005:7), mengatakan bahwa hasil belajar adalah hasil usaha yang dicapai, dilakukan, dan dikerjakan untuk mendapatkan sesuatu kecakapan dan kepandaian. Hasil belajar siswa secara keseluruhan akan dijadikan bahan informasi dan bukti untuk memperbaiki sistem pembelajaran selanjutnya.

Metode asistensi adalah metode yang dirancang agar siswa aktif, yang mana salah seorang siswa akan diberi tanggung jawab untuk menjadi seorang asisten bagi teman-temannya dalam satu kelompok guna menjelaskan materi dan penerapan dari konsep pelajaran yang telah diajarkan oleh guru (Rooijakkers,1993:84). Asistensi sebagai bagian dari metode kooperatif tidak bisa lepas dari pengaruh kerja sama antara guru dan siswa.

Metode ini pada umumnya dilaksanakan di perguruan tinggi, yang mana merupakan bagian dari sistem pengajaran di perguruan tinggi. Pada sistem ini 
seorang pengajar menyampaikan kuliah teori dari suatu bahan, dan asisten yang membantu si pengajar akan memberikan kuliah penerapan berhubungan dengan teori tadi (Rooijakkers, 1993:84). Sesuai dengan kondisi dan situasi yang ada, yaitu di Sekolah Menengah Pertama, maka sistem tersebut diselaraskan. Subjek yang mengajar tidak lagi seorang dosen namun berganti menjadi seorang guru, sementara asisten bukan lagi mahasiswa namun berganti menjadi seorang siswa. Seorang asisten dipilih di dalam kelas mereka dan seorang teman yang telah dikenal oleh siswa lain. Sistem pemilihan seorang asisten tidak semata-mata untuk orang yang disukai dikelas, tetapi seorang asisten memiliki kemampuan pada mata pelajaran tersebut. Tujuan dari sistem ini untuk memudahkan seorang guru untuk mentransfer teori yang diajarkan agar lebih efektif, mengingat keterbatasan waktu yang tergantung pada materi yang banyak. Metode asistensi akan berjalan lancar apabila memenuhi tiga syarat, yaitu: (1) Materi yang diberikan harus merupakan materi yang utuh dan lengkap. Asisten akan membantu siswa secara khusus, pada materi tertentu, dalam penerapan dan latihannya. Jam-jam asistensi akan digunakan oleh siswa untuk mengerjakan beberapa tugas latihan; (2) Harus ada kerja sama antara guru dengan asisten yang membantunya. Seluruh kegiatan asisten harus merupakan bimbingan penerapan praktis dari teori-teori yang telah dijelaskan oleh guru. Dengan komunikasi yang baik maka koordinasi dan pembagian tugas antara guru dan asisten akan berjalan sebagaimana mestinya; dan (3) Materi yang akan dihadapi oleh siswa mencakup soal-soal teori maupun soal-soal penerapan. Dalam hal ini kerja sama antara guru dan asisten sangat diperlukan.

Mengingat metode asistensi merupakan metode kooperatif dalam pembelajaran, maka metode ini relevan sebagai sebuah metode pemecah masalah dalam pelajaran. mengingat alokasi waktu yang terbatas dan materi yang banyak maka sangatlah penting metode ini diterapkan untuk mengatasi masalah tersebut. Metode ini sekaligus membantu guru dalam mengefektifkan proses pembelajaran, karena sebagian tugas guru telah dibantu oleh seorang asisten. Namun demikian bukan berarti seorang asisten menggantikan peran seorang guru, mereka hanya bertugas sebagai perantara untuk memudahkan pemecahan masalah dalam 
pelajaran, yaitu dengan menjelaskan konsep dasar sebuah materi dan aplikasinya dalam soal-soal SBK.

Berdasarkan uraian di atas, dapat dirumuskan permasalahan sebagai berikut: "Apakah metode asistensi dapat meningkatkan hasil belajar SBK materi Memainkan Asambel Musik Tradisional Nusantara pada siswa kelas VIII C SMP Negeri 2 Nguter tahun pelajaran 2016/ 2017?.” Tujuan penelitian ini adalah untuk meningkatkan hasil belajar SBK materi Memainkan Asambel Musik Tradisional Nusantara melalui metode asistensi pada siswa kelas VIII C SMP Negeri 2 Nguter tahun pelajaran 2016/ 2017.

\section{METODE PENELITIAN}

Jenis penelitian yang diambil adalah penelitian tindakan, dikarenakan yang dikenai tindakan adalah sebuah kelas maka disebutlah penelitian tindakan kelas. Penelitian tindakan kelas adalah penelitian yang dilakukan oleh guru ke kelas atau tempat mengajar dengan penekanan pada penyempurnaan atau peningkatan proses dan praktis pembelajaran. Penelitian tindakan dapat dipandang sebagai tindak lanjut dari penelitian deskriptif maupun eksperimen. Dikatakan sebagai kelanjutan penelitian deskriptis karena: (a) penelitian tindakan dimulai dari mencari informasi tentang keadaan sesuatu dalam rangka mencari kelemahan dan mendeskripsikan hal-hal yang terkait dengan kelemahan tersebut; (b) selama penelitian tindakan berlangsung, peneliti mengamati terjadinya tindakan kemudian mendeskripsikan dalam bentuk informasi. Dikatakan sebagai kelanjutan penelitian eksperimen karena tujuan penelitian tindakan adalah mengetahui dampak dari suatu perlakuan tersebut (Arikunto, 2010: 135-136).

Penelitian ini dilaksanakan di SMP Negeri 2 Nguter. Tahap-tahap pelaksanaan kegiatan dilakukan selama kurang lebih lima bulan yaitu sejak bulan Juli sampai dengan November 2016. Dalam penelitian ini, guru SBK kelas VIII C SMP Negeri 2 Nguter bertindak sebagai subjek yang melakukan tindakan kelas. Teman sejawat sesama guru mata pelajaran SBK sebagai observer. Kepala Sekolah bertindak sebagai subjek yang membantu dalam perencanaan dan pengumpulan 
data. Subjek yang menerima tindakan adalah siswa kelas VIII C SMP Negeri 2 Nguter tahun pelajaran 2016/ 2017 sebanyak 32 siswa.

Adapun langkah-langkah penelitian untuk setiap siklus pembelajaran SBK adalah sebagai berikut:

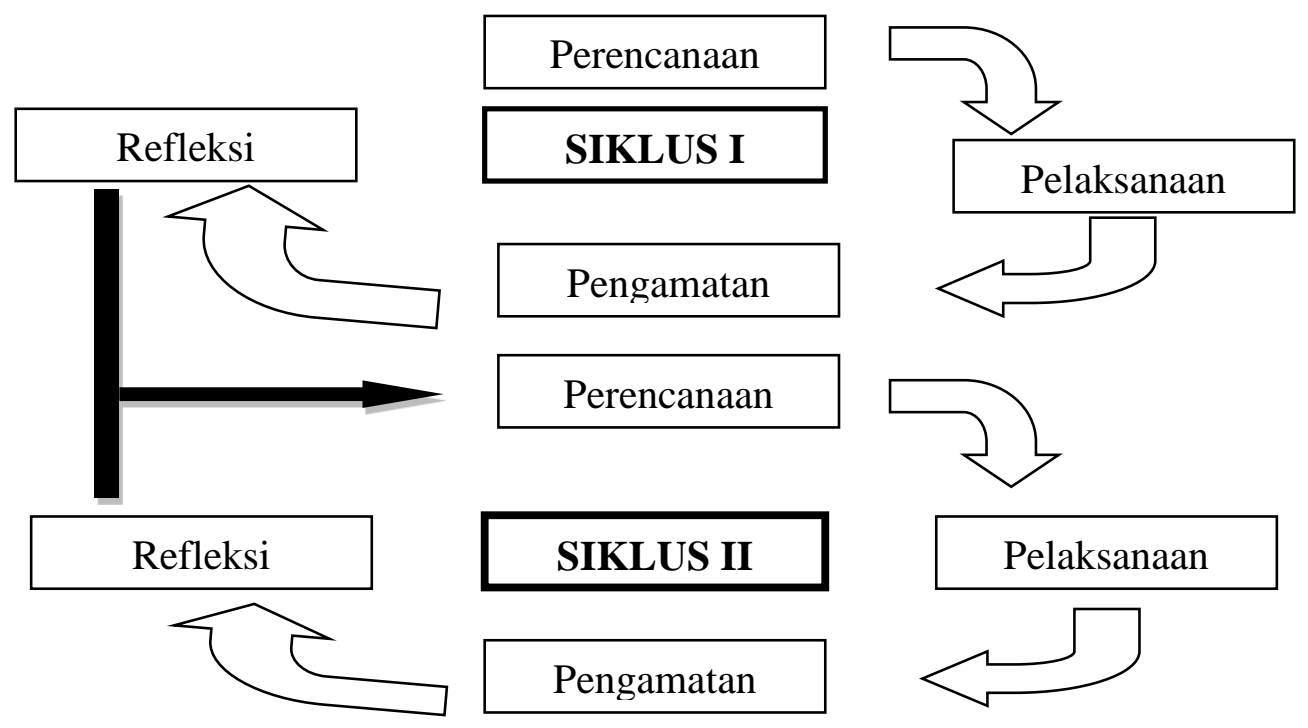

Gambar 1 Siklus penelitian tindakan (Arikunto,2010)

Teknik pengumpulan data yang digunakan adalah: (a) Tes, observasi, wawancara, dan dokumentasi. Tes adalah serentetan pertanyaan atau latihan serta alat lain yang digunakan untuk mengukur keterampilan, pengetahuan inteligensi, kemampuan atau bakat yang dimiliki oleh individu dan kelompok (Arikunto, 2010: 193). Tes digunakan untuk memperoleh data tentang hasil belajar SBK siswa sebelum penelitian, selama penelitian dan setelah penelitian dilaksanakan. Observasi yang digunakan adalah observasi sistematis, yaitu observasi yang dilakukan oleh pengamat dengan menggunakan pedoman sebagai instrumen pengamatan.

Instrumen yang digunakan dalam penelitian ini adalah: soal tes, lembar observasi, dan lembar wawancaradan.Lembar observasi dugunakan peneliti sebagai pedoman melakukan observasi atau pengamatan guna memperoleh data yang akurat dalam pengamatan. Lembar observasi juga digunakan untuk memonitor dan mengevaluasi setiap tindakan agar kegiatan observasi tidak terlepas dari konteks 
permasalahan dan tujuan penelitian. Tes digunakan untuk melihat seberapa besar penguasaan konsep SBK siswa terhadap materi yang diajarkan. Indikator keberhasilan kinerja dalam penelitian ini adalah meningkatnya hasil belajar SBK siswa yang ditunjukkan dengan meningkatnya nilai rata-rata kelas, minimal menjadi 75,00 dan meningkatnya persentase ketuntasan siswa minimal $85 \%$.

\section{HASIL DAN PEMBAHASAN}

Sebelum melaksanakan proses penelitian, terlebih dahulu guru melakukan kegiatan survei awal dengan tujuan mengetahui keadaan nyata di lapangan. Berdasarkan survei awal tersebut, dapat dilihat dalam tabel nilai SBK materi Memainkan Asambel Musik Tradisional Nusantara sebagai berikut. Sebanyak 15 siswa $(45,9 \%)$ belum mencapai ketuntasan belajar, sedang hanya 17 siswa $(53,1 \%)$ yang sudah mencapai ketuntasan belajar, dengan nilai rata-rata kelas 70,1. Data tersebut menjadi landasan bagi guru untuk melaksanakan penelitian, yang kemudian penjelasan secara lengkap dapat dilihat pada uraian berikut ini.

Pada penelitian ini guru melakukan observasi terhadap aktivitas siswa dan guru (yang dilakukan oleh guru kolaboran). Berdasarkan hasil pengamatan terhadap aktivitas siswa dalam proses pembelajaran pada siklus I diperoleh data sebagai berikut:

Tabel 1. Aktivitas Siswa dalam Proses Pembelajaran pada Siklus I

\begin{tabular}{clcc}
\hline \multirow{2}{*}{ No } & \multicolumn{1}{c}{ Kegiatan yang diamati } & \multicolumn{2}{c}{ Jumlah } \\
\cline { 3 - 4 } & & Siswa & Persentase \\
\hline 1 & Kesiapan menerima pelajaran & 25 & $94 \%$ \\
\hline 2 & Menjawab dan bertanya tentang materi & 32 & $78 \%$ \\
\hline 3 & Mengerjakan tugas yang diberikan guru & 28 & $100 \%$ \\
\hline 4 & $\begin{array}{l}\text { Mempelajari buku paket atau buku lain yang } \\
\text { relevan }\end{array}$ & & $88 \%$ \\
\hline
\end{tabular}

Dari tabel di atas diperoleh bahwa pada siklus I, data kesiapan siswa menerima pelajaran sebanyak 30 siswa (94\%), kegiatan menjawab dan bertanya siswa sebanyak 25 siswa (78\%), kegiatan mengerjakan tugas yang diberikan oleh guru sebanyak 32 siswa (100\%), dan kegiatan mempelajarai buku paket dan buku yang relevan sebanyak 28 siswa (88\%). Maka dapat dikatakan kesiapan siswa sudah menunjukkan angka yang baik walaupun masih terdapat 2 siswa (6\%) yang dapat 
dikatakan belum siap menerima pelajaran. Sebanyak 25 siswa (78\%) telah terpenuhi pada aspek kegiatan menjawab dan bertanya perihal materi serta kegiatan mempelajari buku paket. Hal tersebut membuat guru harus lebih meningkatkan keaktifan siswa dalam tiga kegiatan tersebut dengan cara memberikan motivasi terhadap siswa. Lain halnya dengan kegiatan mengerjakan tugas, pada aspek ini siswa sudah $100 \%$ melaksanakannya, walaupun hasil dari tugas tersebut belum maksimal dan harus diperbaiki pada siklus selanjutnya.

Dalam observasi guru, objek yang diamati meliputi kinerja guru dalam pembelajaran yang telah dilakukan pada siklus I yang dibantu oleh guru kolaboran, teman sejawat.

Secara garis besar guru telah melaksanakan tahap-tahap dalam pembelajaran mulai dari pembukaan, kegiatan inti sampai pada penutup, akan tetapi terdapat kekurangan-kekurangan yaitu: (1) Guru belum maksimal dalam memberikan apersepsi dikarenakan keterbatasan waktu yang dimiliki; (2) Guru belum menciptakan suasana belajar yang menyenangkan bagi siswa, guru masih kelihatan kaku; (3) Guru masih belum memberikan motivasi kepada siswa secara merata, seharusnya motivasi ini diberikan tidak hanya kepada siswa yang berkemampuan kurang tetapi juga berkemampuan lebih; (4) Dalam memberikan tugas, harusnya guru membuat soal yang berbeda agar kemampuan siswa dapat terasah. Soal yang diberikan untuk pekerjaan rumah masih sedikit.

Berdasarkan pengamatan secara keseluruhan menunjukkan bahwa guru sudah melaksanakan pembelajaran dengan cukup baik dan kekurangan yang terdapat pada siklus I akan dijadikan pedoman untuk perbaikan pada silkus II.

Proses pembelajaran SBK dengan menggunakan metode Asistensi, pada siklus I belum menunjukkan hasil yang diharapkan. Hasil data yang terkumpul pada siklus I masih terdapat beberapa aspek yang perlu mendapatkan perbaikan yaitu: (1) Guru belum memberikan motivasi secara intensif dan menyeluruh. Hal ini berkaitan dengan hasil observasi pada siklus I dilihat dari hasil kesiapan siswa yang kurang sehingga tidak mustahil dalam proses pembelajaran belum nampak proses pembelajaran yang menyenangkan; (2) Efektifitas waktu harus dijaga, agar siswa dapat konsentrasi dalam melaksanakan proses pembelajaran. Kesan santai dalam 
suasana belajar jangan membuat siswa menjadi tidak fokus pada materi; (3) Guru belum maksimal dalam pengelolaan kelas terutama pada pemberian bimbingan dan penguatan yang merata baik kepada seluruh siswa.

Dari data hasil pembelajaran SBK pada siklus I, diperoleh bahwa sebanyak 23 siswa $(71,8 \%)$ sudah memenuhi ketuntasan belajar, sedangkan sebanyak 9 siswa $(28,2 \%)$ belum tuntas belajar, dengan nilai rata-rata kelas mencapai 75,2. Hal ini mengindikasikan bahwa pembelajaran SBK masih perlu ditingkatkan.

Berdasarkan hasil pengamatan terhadap aktivitas siswa dalam proses pembelajaran pada siklus II diperoleh data sebagai berikut:

Tabel 2. Aktivitas Siswa dalam Proses Pembelajaran pada Siklus II

\begin{tabular}{cccc}
\hline No & Kegiatan yang diamati & \multicolumn{2}{c}{ Jumlah } \\
\cline { 3 - 4 } & & Siswa & Persentase \\
\hline 1 & Kesiapan menerima pelajaran & 32 & $100 \%$ \\
\hline 2 & Menjawab dan bertanya tentang materi & 30 & $94 \%$ \\
\hline 3 & Mengerjakan tugas yang diberikan guru & 32 & $100 \%$ \\
\hline 4 & Mempelajari buku paket atau buku lain yang relevan & 30 & $94 \%$ \\
\hline
\end{tabular}

Dari data di atas diperoleh bahwa pada siklus II, data kesiapan siswa menerima pelajaran sebanyak 32 siswa (100\%), kegiatan menjawab dan bertanya tentang materi sebanyak 30 siswa (94\%), kegiatan mengerjakan tugas 32 siswa (100\%), dan kegiatan mempelajari buku paket atau buku yang relevan sebanyak 30 siswa (94\%). Maka dapat dikatakan kesiapan siswa menerima pelajaran sudah menunjukkan angka yang baik, yang dibuktikan dengan seluruh siswa sudah siap menerima pelajaran. Pada penilaian mengenai kegiatan menjawab dan bertanya sudah menunjukkan peningkatan yang cukup baik bila dibandingkan dengan siklus I. Pada kegiatan mengerjakan tugas sudah seluruhnya siswa antusias untuk mengerjakan selanjutnya diikuti dengan peningkatan pada kegiatan mempelajari buku paket yang mencapai 94\%. Dari hasil siklus II tersebut dapat terlihat hasil yang cukup memuaskan dari peningkatan pembelajaran SBK dengan menggunakan metode Asistensi, hal ini tidak lepas dari kerja sama guru dan siswa.

Secara garis besar guru telah melaksanakan tahap-tahap dalam pembelajaran mulai dari pembukaan, kegiatan inti sampai pada penutup. Hasil observasi pada siklus I telah menjadi acuan pada siklus II ini, yang mana guru telah melakukan tahap-tahap pelaksanaan pembelajaran sesuai prosedur. Hal ini terlihat 
dari daftar observasi guru di atas. Perbaikan-perbaikan terhadap kekurangan pada siklus I telah dilakukan pada siklus II dengan memberikan fokus penguatan pada seluruh siswa tanpa terkecuali sehingga siswa lebih termotivasi lagi dalam melaksanakan proses belajar mengajar.

Dari hasil pengamatan, siswa mengalami peningkatan yang lebih baik dan sangat memuaskan. Karena siswa sudah dapat memahami dan mengikuti proses pembelajaran dengan baik serta minat dan Aktivitas siswa dapat meningkat dengan baik karena ada kemauan yang besar dalam diri siswa. Hasil refleksi pada siklus II meliputi, antara lain perenungan proses pembelajaran yang telah dilaksanakan, perenungan hasil pelaksanaan metode yang digunakan dalam proses pembelajaran, pengambilan kesimpulan dan keputusan berdasarkan proses yang telah dilaksanakan pada setiap siklus.

Hasil tes pada siswa kelas VIII C dalam siklus II diperoleh sebanyak 29 siswa $(90,6 \%)$ telah mencapai ketuntasan belajar, namun masih terdapat 3 siswa $(9,4 \%)$ yang belum mencapai ketuntasan belajar. Nilai rata-rata kelas adalah 80 . Dari hasil pembelajaran SBK pada siklus II dapat dikatakan bahwa penelitian ini telah mengalami peningkatan baik dari segi tes maupun non tes.

Dari data perbandingan hasil siklus I dan II dapat dilihat bahwa sebanyak 23 siswa $(71,8 \%)$ telah mencapai ketuntasan belajar sedangkan siswa yang belum mencapai tuntas belajar sebanyak 9 siswa (28,2\%). Hasil ini dikategorikan cukup memuaskan dalam ketuntasan belajar secara klasikal, tetapi persentase nilai ketuntasan secara individu belum memuaskan karena ada 28,2\% siswa yang belum tuntas belajar. Pada siklus II terjadi kenaikan terhadap jumlah ketuntasan belajar yaitu sebanyak 29 siswa (90,6\%). Adapun siswa yang belum mencapai tuntas sebanyak 3 siswa $(9,4 \%)$, hasil ini dikategorikan memuaskan walaupun belum mencapai $100 \%$. Sementara nilai rata-rata kelas pada siklus I dan II berturut-turut yaitu 75,2 dan 80 . 


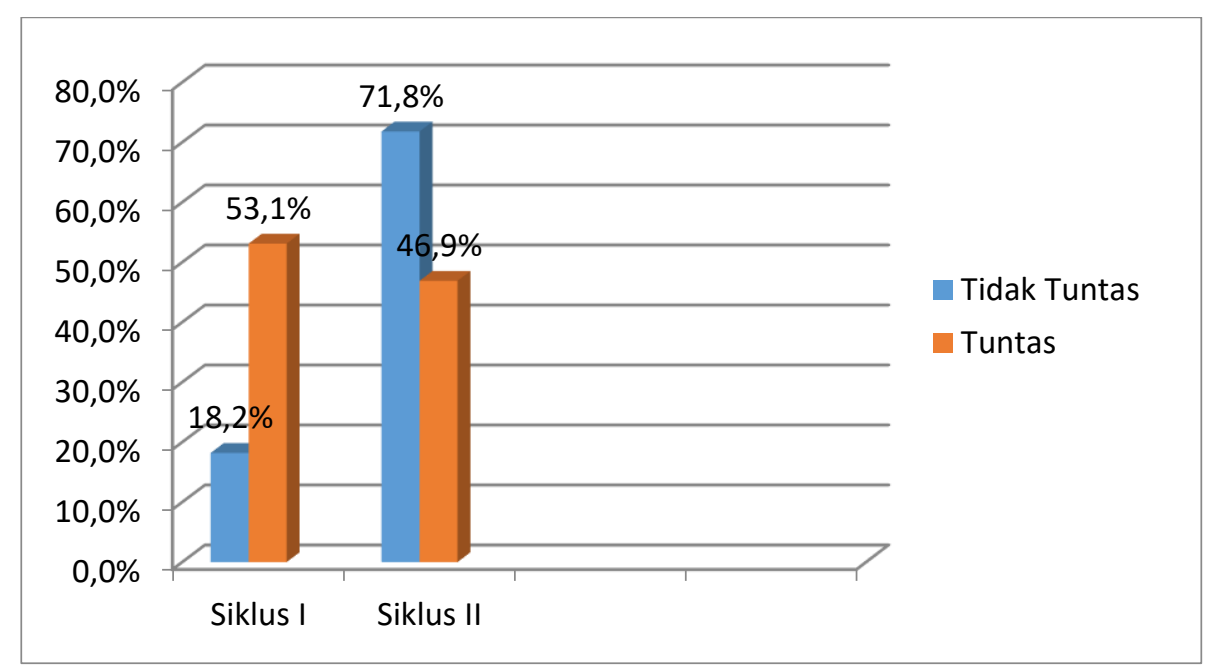

Gambar 2. Perbandingan Persentase Hasil Tes Siklus I dan II

Pengamatan terhadap aspek non tes meliputi kesiapan siswa melaksanakan proses belajar mengajar, antusias bertanya dan menjawab berkaitan dengan materi yang diajarkan oleh guru, kegiatan mengerjakan tugas yang diberikan oleh gurudan kegiatan mempelajari buku paket atau buku lain yanga relevan dengan materi. Semua aspek tersebut dapat dilihat dalam tabel berikut.

Tabel 3. Perbandingan Persentase Aktivitas Siswa dalam Proses Pembelajaran SBK pada Siklus I dan Siklus II

\begin{tabular}{clcc}
\hline \multirow{2}{*}{ No. Aspek } & \multicolumn{1}{c}{ Kegiatan yang diamati } & \multicolumn{2}{c}{ Persentase } \\
\cline { 3 - 4 } & & Siklus I & Siklus II \\
\hline 1 & Kesiapan menerima pelajaran & $94 \%$ & $100 \%$ \\
\hline 2 & Menjawab dan bertanya tentang materi & $78 \%$ & $94 \%$ \\
\hline 3 & Mengerjakan tugas yang diberikan guru & $100 \%$ & $100 \%$ \\
\hline 4 & Mempelajari buku paket atau buku lain yang relevan & $88 \%$ & $94 \%$ \\
\hline
\end{tabular}

Dari data di atas diperoleh keterangan bahwa terjadi kenaikan dari siklus I terhadap siklus II pada masing-masing indikator. Dari data kesiapan dari 94\% menjadi 100\%, yang ditunjukkan dengan kesiapan siswa menerima pelajaran. Dalam aspek menjawab dan bertanya perihal materi juga mengalami kenaikan sebesar $16 \%$ yaitu dari $78 \%$ menjadi $94 \%$. Kenaikan antusias untuk menjawab dan bertanya ini ditunjukkan dengan aktifnya siswa yang mempunyai kemampuan sedang dan rendah. Mereka bertanya seputar materi yang sedang diajarkan oleh guru. Kenaikan yang signifikan ini sangat berpengaruh bagi lancarnya kegiatan belajar mengajar SBK khususnya pembelajaran materi Memainkan Asambel Musik Tradisional Nusantara yang ditunjukkan dengan mulai aktifnya siswa 
untuk menjawab baik secara lisan maupun tulisan. Hasil pada kedua siklus sudah menunjukkan hasil yang memuaskan yaitu dengan mancapai $100 \%$. Semua hasil tersebut tidak lepas dari kerja sama antara guru dan siswa. Berikut ini grafik tentang perbandingan persentaseaktivitas pembelajaran pada siklus I dan II.

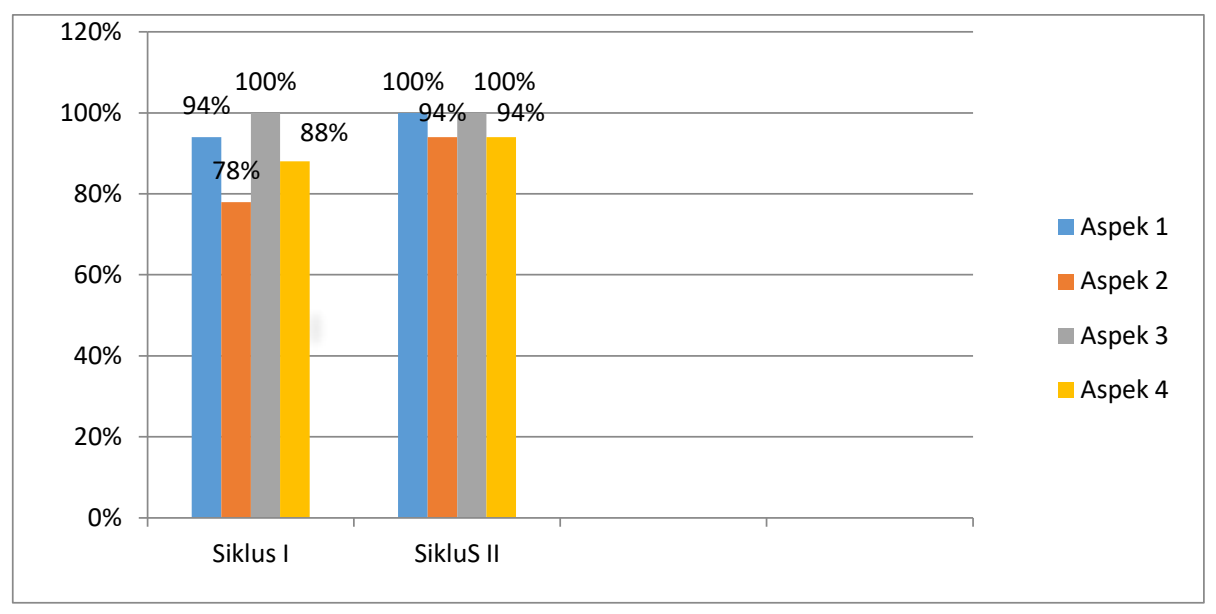

Gambar 4. Perbandingan Persentase Aktivitas Pembelajaran Siklus I dan II

Semua aspek yang terdapat dalam lembar observasi guru telah dilaksanakan oleh guru yaitu dari pendahuluan sampai penutup. Guru kolaboran memberikan saran kepada gurudalam rangka pembenahan-pembenahan terhadap kekurangan yang ada pada siklus I, kemudian diperbaiki pada siklus II, yakni guru telah memberikan penguat dan motivasi yang merata kepada semua siswa, sehingga proses pembelajaran terlihat hidup dan menyenangkan.

Hasil pengamatan terhadap sikap siswa dalam mengikuti proses pembelajaran SBK dengan menggunakan metode Asistensi. Siswa-siswa yang mempunyai nilai tinggi (ditunjukkan dengan hasil nilai yang tinggi pada siklus I dan II) berpendapat bahwa pembelajaran dengan metode Asistensi sangat menyenangkan, karena terdapat berbagai tantangan. Siswa-siswa yang mempunyai nilai sedang (yaitu siswa yang memiliki nilai tes antara 70 sampai 85) berpendapat bahwa pembelajaran yang sedang berlangsung sangat menyenangkan karena ada tantangan. Sementara siswa yang mempunyai keterampilan nilai rendah (siswa yang memilki nilai tes di bawah angka 70) memiliki pendapat bahwa pembelajaran yang sedang berlangsung cukup menyenangkan walaupun masih ada kesulitan dalam mengerjakan soal. 


\section{SIMPULAN}

Berdasarkan hasil penelitian tindakan kelas dan pembahasan yang disajikan, dapat diambil kesimpulan bahwa penelitian tindakan kelas ini telah berhasil. Terbukti bahwa metode asistensi dapat meningkatkan hasil belajar SBK materi Memainkan Asambel Musik Tradisional Nusantara pada siswa kelas VIII C SMP Negeri 2 Nguter tahun pelajaran 2016/ 2017.

\section{REFERENSI}

Arikunto, Suharsimi. (2010). Manajemen Penelitian. Jakarta: PT. Rineka Cipta.

Moleong. (2004). Metodologi Penelitian Kualitatif. Bandung :PT Remaja Rosdakarya.

Poerwadarminto. (2005). Kamus Umum Bahasa Indonesia. Jakarta: Balai Pustaka.

Rooijakkers, Ad. (1993). Mengajar Dengan Sukses. Jakarta: PT. Grasindo.

Slameto. (2003). Belajar dan Faktor-Faktor yang Mempengaruhinya. Jakarta: PT. Rineka Cipta.

Sugiyanto. (2007). Model-model Pembelajaran Inovatif. Surakarta :Panitia Sertifikasi Guru Rayon 13. 